\title{
SHADING PERFORMANCE ON TERRACED HOUSE FACADES IN PUTRAJAYA, MALAYSIA
}

\author{
Ahmad Sanusi Hassan and Mohammed Salem Obaid Bakhlah \\ School of Housing, Building and Planning \\ Universiti Sains Malaysia 11800 USM, Penang, Malaysia
}

\section{ABSTRACT}

This study evaluates shading performance on house facades of selected three terraced houses in Putrajaya, Malaysia as the case studies. Terraced house type is selected for the case study because it is the most popular house type built in this country to house an increase of the urban population. Its total number built in urban area increases from $27 \%$ of the total dwellings in 1980 to $40 \%$ in 1990 , and to slightly more than 60 per cent in 2000. The Case Study A, B, and C are atypical style of terraced house facade designs built in Putrajaya. These postmodern designs exhibit a range of complex geometric elements blending of colonial and traditional elements with colorful styles on the house facade. In this study, the time at which the sun path perpendicular to the house facade will be used to gain the results of shading performances when the house facades have their maximum exposure to the direct sunlight. The house facade was divided into two main parts which are opaque and glazing surface elements. The amount of shading area on the opaque and glazing surface was simulated using the SunTool program. In conclusion, the Case Study $\mathrm{C}$ had the highest average percentage of the shading area, which is $64.43 \%$, followed by the Case Study A $60.41 \%$ and Case Study B 56.29\%. These results showed that the facade designs had excellent horizontal shading elements with roof overhangs for high angle sunlight but they had weak vertical shading elements due to a lack of considerations of louvered elements to block low angle sunlight.

Key Words: Shading Performance; Facade; Terraced Houses; Malaysia

\section{INTRODUCTION}

Design with excellent shading devices blocking the sunlight to the house facade is crucial. Poor design allows house wall exposure to direct sunlight; as a result, it exposes the house facade to solar radiation. Solar radiation absorbs the heat to the facade opaque and glazing surface (wall) which reradiates the heat to the indoor area; as a result, it causes insolation which increases the indoor air temperature. The higher is the amount of insolation, the higher is the temperature (Mazloomi, Hassan, Bagherpour and Ismail, 2010; Djamila, Ming and Kumaresan, 2011). Having a house facade exposed to direct sunlight thus must be avoided. Being located in equatorial region, this country has abundant sunlight with solar radiation to radiate the heat (Zain-Ahmed, Sopian, Abidin and Othman, 2002). Duration of the daytime is about equal to the night time with small variations of its temperature. The average hours of sunshine per day in Malaysia is about 6 hours, approximately half of the total daytime's hours (Dale, 1964; Danny and Joseph, 2001). It is the objective of this research to evaluate the amount of shading area to solar radiation on house facades of selected three terraced houses with post modern style in Putrajaya, Malaysia.

Terraced house type is selected for the case study because it is the most popular house type built in this country to house an increase of urban population (Hassan, 2001). Its total number built in urban area increases from $27 \%$ of the total dwellings in 1980 to $40 \%$ in 1990 , and to slightly more than 60 per cent in 2000 (Department of Statistics Malaysia, 2000). The assessments are to identify a direction of the terraced house designs in Malaysia in relation to the awareness to passive solar design 
on the house façade. The analysis will be able to provide significant data and information of the amount of shading and exposed area on the house facade which reradiates the heat inside the house. Solar radiation affects the level of indoor air temperature. It influences the amount of electricity consumption when the occupants use air conditioning to reduce the indoor air temperature to suit their body comfort level (Abdul Rahman, 1995).

This type of fundamental research study is important as it is able to provide real data to the architects and those who involve in the housing industry as a reference to the house facade design. The position of the sun and house determines the intensity of solar radiation striking on various surfaces of house facades (Hussein and Rahman, 2009). The amount of solar radiation striking a given surface of a windows, doors and walls changes constantly as a result from the changing position and angle of the sun (Hassan and Ramli, 2010; Singh, Mahapatra and Atreya, 2010). The diurnal and annual patterns of the sun path in the sky depend on the latitude of the building location (Feriadi and Nyuk, 2004). The house facade design will be evaluated using its percentages of shading area.

\section{THE CASE STUDIES}

The scope of this study is to do a survey on facade of terraced houses built after 1990s. The good example of this type of the terraced houses is terraced houses in Putrajaya. Putrajaya is the latest new town built in Malaysia and currently becomes an administrative city for the federal government. This new town began its construction in 1995 after its master plan was approved by the Prime Minister and its cabinets. Its location is in district of Sepang, Selangor, about 25 kilometres from Kuala Lumpur and 20 kilometres from Kuala Lumpur International Airport (KLIA). The total area is 14,780 hectare, developed for federal administrative uses and governing purposes, and it is currently managed by Putrajaya Corporation as the city council. Putrajaya consists of 15 sections known as precincts with administrative buildings, commercial area, residential houses, parks and open spaces. The central area has five precincts, each precinct with 4,050 housing units while the perimeter area covers 10 precincts, planned to have 3,100 housing units' each (Hassan, 1999). The selected terraced houses for this survey are as follows:

1. The Case Study A: The address is at No. 12, P9D3 Street, Precint 9, 62250 Putrajaya (Figure 1).

2. The Case Study B: The address is at No. 25, P16D2 Street, Precint 16, 62150 Putrajaya (Figure 2).

3. The Case Study C: The address is at No. 32, P8E3 Street, Precint 8, 62250 Putrajaya (Figure 3).

The Case Study A, B, and C are atypical style of terraced house facade design built after 1990s with post modern style. The design exhibits a range of complex geometric elements blending of modern, colonial and traditional elements with colorful styles on the house facade. The overall design deviates dramatically from regular and simple compositions of modern architecture which are an expression of architectural purity and simple color scheme based on the emphasis on universal style (Hassan, 2005). In case of houses built at Putrajaya, they represent showcases for the present and future direction of house designs in Malaysia. 


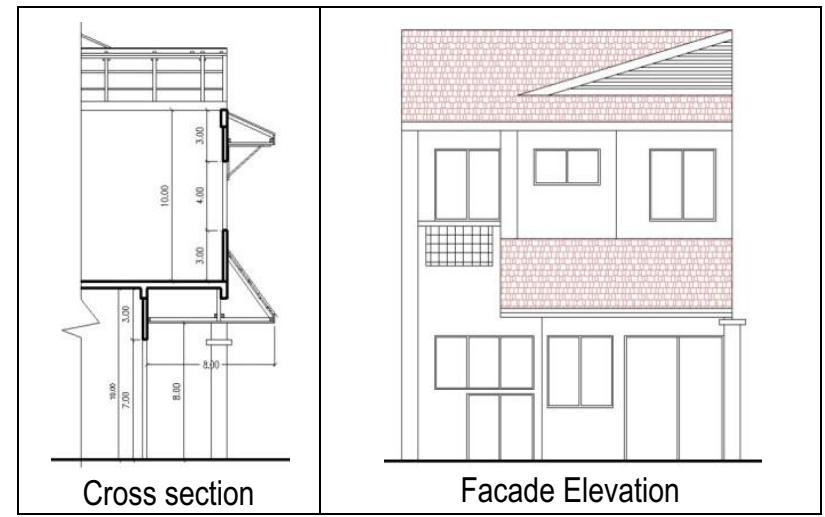

Figure 1. House facade's cross section (left) and front elevation (right) for the Case Study A.

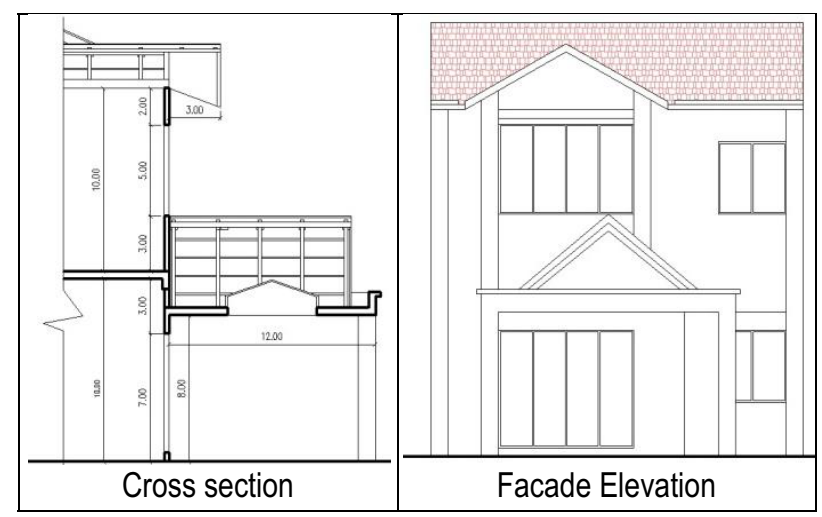

Figure 2. House facade's cross section (left) and front elevation (right) for the Case Study B.

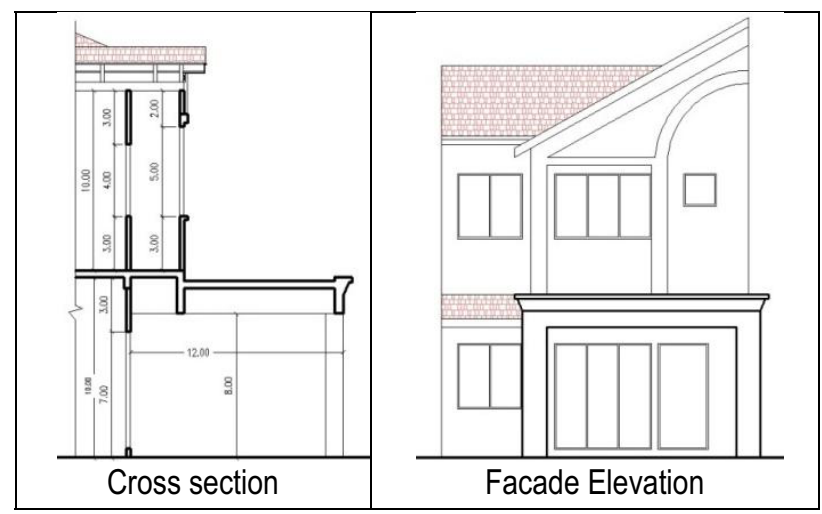

Figure 3. House facade's cross section (left) and front elevation (right) for the Case Study C.

\section{MATERIALS AND METHODS}

This survey will be conducted using the SunTool software at a position when the sun path is perpendicular to the house facade either during morning (east $90^{\circ}$ ) or evening (west $270^{\circ}$ ) session in the selected case studies located in Putrajaya at latitude N3.1 $1^{\circ}$ and longitude E101.4 $4^{\circ}$. The reason for this orientation is that terraced houses are mass produced house type built at various orientation to the sun path. In this study, the time at which the sun path perpendicular to the house facade will be used in order to gain the results when the house facade has its exposure perpendicular to direct sunlight. By applying this method, the survey will be able to identify effectiveness level of the house facade on shading design. Limitation of this survey is that the position of the sun path changes from time to time 
during the daytime. In order to get perpendicular angle of the sunlight to the east $\left(90^{\circ}\right)$ and west $\left(270^{\circ}\right)$, the researcher has calculated the required perpendicular angle of the sun path with a reference to the SunTool Software (Bakhlah and Hassan, 2012). Time and date when the sun paths are perpendicular to the house facade are illustrated in Table 1. The other limitation is that there are at certain times and dates that the sun path's azimuth is not possible to have perfectly perpendicular at $90^{\circ}$. In these cases, the closest azimuths nearest to $90^{\circ}$ will be used in simulation from $7 \mathrm{am}$ to $6 \mathrm{pm}$ (Bakhlah and Hassan, 2012; Arab and Hassan, 2012) as follows:

Table 1. Time, date and azimuth of the sun at $90^{\circ}$ or nearest to $90^{\circ}$ used in the simulation in calculating shading area on the house facades.

\begin{tabular}{|c|c|c|c|}
\hline Orientation & Time & Date & Azimuth \\
\hline \multirow{4}{*}{ East $90^{\circ}$} & $7 \mathrm{am}$ & 23 March & $90^{\circ}$ \\
\cline { 2 - 4 } & $8 \mathrm{am}$ & 25 March & $90^{\circ}$ \\
\cline { 2 - 4 } & $9 \mathrm{am}$ & 27 March & $89.8^{\circ}$ \\
\cline { 2 - 4 } & $10 \mathrm{am}$ & 28 March & $90.1^{\circ}$ \\
\cline { 2 - 4 } & $11 \mathrm{am}$ & 29 March & $90^{\circ}$ \\
\cline { 2 - 4 } West 270 & $12 \mathrm{pm}$ & 29 March & $92.2^{\circ}$ \\
\hline \multirow{5}{*}{} & $1 \mathrm{pm}$ & 16 September & $90.5^{\circ}$ \\
\cline { 2 - 4 } & $2 \mathrm{pm}$ & 29 March & $89.8^{\circ}$ \\
\cline { 2 - 4 } & $3 \mathrm{pm}$ & 18 September & $89.8^{\circ}$ \\
\cline { 2 - 4 } & $4 \mathrm{pm}$ & 26 March & $89.9^{\circ}$ \\
\cline { 2 - 4 } & $5 \mathrm{pm}$ & 24 March & $89.9^{\circ}$ \\
\cline { 2 - 4 } & $6 \mathrm{pm}$ & 22 March & $89.9^{\circ}$ \\
\hline
\end{tabular}

All data such as the location (Putrajaya), facade orientation (east or west), time and date were keyed in solar position calculator in the SunTool software (Figure 4) to get correct position before the simulation will be able to generate. Later, the dimension of the house facade which are the depth of exterior shading devices, floor height, wall width and sill height are drawn in the SunTool programme. With these solar position and dimension of the house facade, the software will be able to generate in its drawing section indicating the sun beam and shade on the house facades. In propose of calculation the amount of shading area of the house facades oriented to east $90^{\circ}$ and west $270^{\circ}$, each house front facade is divided to two main parts namely opaque and glazing elements. The amount of shading area of opaque and glazing surface elements will be later generated by the SunTool program. The data analysis programs such as Microsoft Excel also will be conducted in this study. The amount of shading area will be calculated using the following formula (Figure 4):

(1). $S_{G A}=S_{G H} \times G_{W}$

Where: $S_{G A}=$ Shaded glazing area, $S_{G H}=$ Shading Glazing Height, $G_{W}=$ Glazing Width

(2). $S_{O A}=S_{H} \times L-S_{G A}$

Where: $S_{O A}=$ Shaded opaque area, $S_{H}=$ Shading Height, $L=$ Length of facade

(3). $E_{O A}=T_{O A}-S_{O A}$

Where: $E_{O A}=$ Exposed opaque area, $T_{O A}=$ Total Opaque Area

(4). $T_{O A}=F_{H} \times L-T_{G A}$

Where: $F_{H}=$ Floor Height (Ground or First Floor), $T_{G A}=$ Total Glazing Area

(5). $T_{G A}=G_{H} \times G_{W}$

Where: $\mathrm{G}_{H}=$ Glazing Height

(6). $E_{G A}=T_{G A}-S_{G A}$

Where: $E_{G A}=$ Exposed glazing area, $T_{G A}=$ Total Glazing Area 


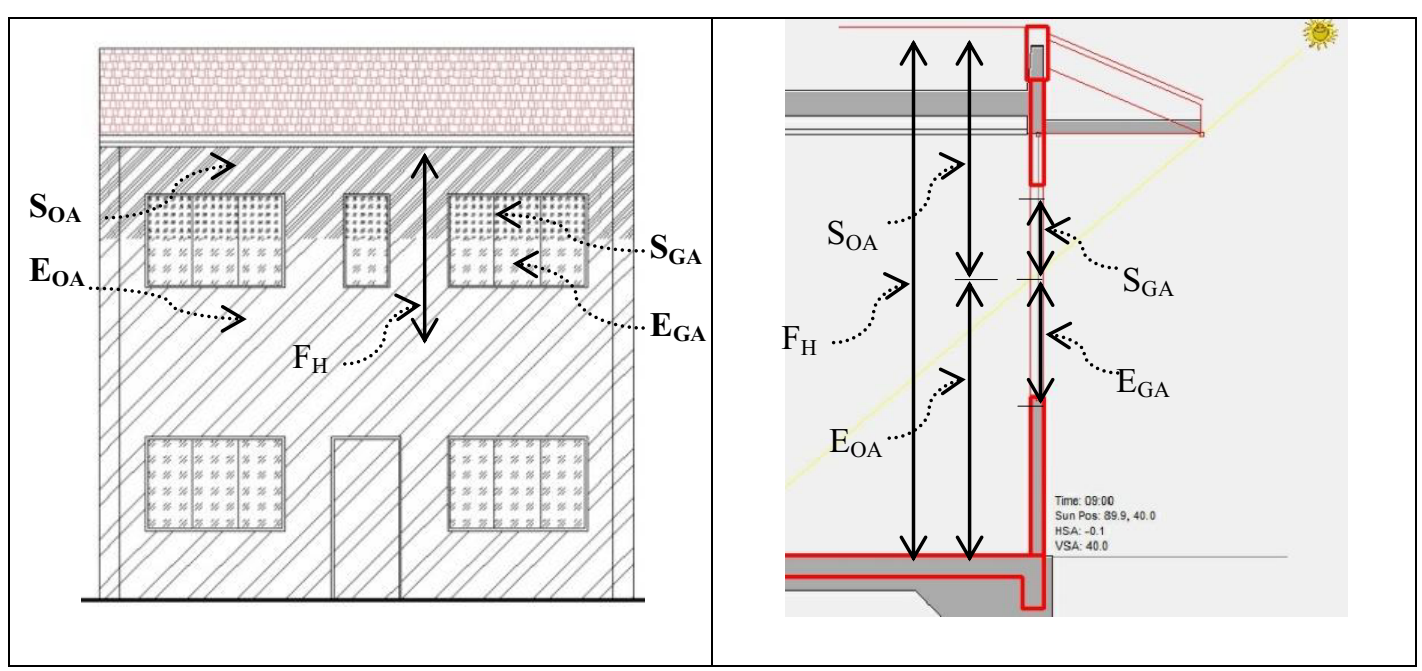

Figure 4. Abbreviation of the equations of the house facade (left) and its cross section (right).

\section{RESULTS}

The analysis compares results of the shading areas on the ground floor level (Storey 1) and first floor level (Storey 2) of the house facade for the Case Study A, B and C. Figure 5, 6 and 7 show the results of shading area on the house facade from simulations in the SunTool Program. The results of shading area from $7 \mathrm{am}$ to $6 \mathrm{pm}$ will be elaborated in percentages which represent shading area of windows, opaque wall and house front facade divided by the total area of windows, opaque wall and facade respectively. For the house facade selected in the Case Study A, it has the total area $400 \mathrm{ft}^{2}$ which consists of window $\left(74 \mathrm{ft}^{2}\right)$ and opaque wall area $\left(326 \mathrm{ft}^{2}\right)$ of the ground floor level and first floor level. The facade of the ground floor level has window area $34 \mathrm{ft}^{2}$ and opaque wall area $166 \mathrm{ft}^{2}$ while its first floor level has window area $40 \mathrm{ft}^{2}$ and opaque wall area $160 \mathrm{ft}^{2}$. For the Case Study B, its total facade area is $440 \mathrm{ft}^{2}$, window area $124 \mathrm{ft}^{2}$ and opaque wall area $316 \mathrm{ft}^{2}$. The facade of the ground floor has window area $68 \mathrm{ft}^{2}$ and opaque wall area $152 \mathrm{ft}^{2}$ while its first floor level has window area $56 \mathrm{ft}^{2}$ and opaque wall area $164 \mathrm{ft}^{2}$. For the Case Study C, its total facade area is $382 \mathrm{ft}^{2}$, window area $99 \mathrm{ft}^{2}$ and opaque wall area $283 \mathrm{ft}^{2}$. The facade of the ground floor has window area $55 \mathrm{ft}^{2}$ and opaque wall area $137 \mathrm{ft}^{2}$ while its first floor level has window area $44 \mathrm{ft}^{2}$ and opaque wall area $146 \mathrm{ft}^{2}$.

From the results of shading area on the facade of the selected case studies (Figure 5, 6 and 7), a comparison will be carried out in percentages. The Case Study $\mathrm{C}$ had the highest average percentage of shading area with $64.43 \%$, followed by Case Study A $60.41 \%$ and Case Study B $56.29 \%$. From the total shading area on the house facades, it can be noted that the Case Study A had higher percentages of the shading area than the Case Study B from 7.00am to 10.00am and from 2.00pm to 6.00pm with an average difference $7.94 \%$ ranging from minimum $3.96 \%$ to maximum $10.76 \%$ while it had lower percentages than the Case Study B from $11.00 \mathrm{am}$ to $1.00 \mathrm{pm}$ with an average difference $7.37 \%$ ranging from minimum $2.63 \%$ to maximum $10 \%$. The Case Study A however had lower percentages than the Case Study C most of the times from 7.00am to $9.00 \mathrm{am}$ and from $11.00 \mathrm{am}$ to $1.00 \mathrm{pm}$ and from $4.00 \mathrm{pm}$ to $6.00 \mathrm{pm}$. The average differences were $5.97 \%$ ranging from minimum $1.6 \%$ to maximum $10.97 \%$. The Case Study A only had higher percentages of shading area than the Case Study $C$ at $10.00 \mathrm{am}$ and from $2.00 \mathrm{pm}$ to $3.00 \mathrm{pm}$ with an average difference of $1.82 \%$. Moreover the Case Study B had lower percentages than the Case Study $C$ all the daytime except at $12.00 \mathrm{pm}$ with $100 \%$ shading area. The average difference was $8.88 \%$ ranging from $0.22 \%$ to $11.52 \%$. 
The analysis besides discusses on performances on the amount of shading area on the house facade for each Case Study. These performances are divided to 4 categories namely Category 1 from $0 \%$ to 25 as very weak, Category 2 from $26 \%$ to $50 \%$ as weak, Category 3 from $50 \%$ to $75 \%$ as intermediate, and above $75 \%$ as very good. For the Case Study $A$, the performances were under very weak and weak category from $7.00 \mathrm{am}$ to $8.00 \mathrm{am}$ and from $5.00 \mathrm{pm}$ to $6.00 \mathrm{pm}$ with the percentages ranging from $27.58 \%$ to $43.41 \%$, while it was under intermediate category ranging from $59.42 \%$ to $71.33 \%$ from $9.00 \mathrm{am}$ to $10.00 \mathrm{am}$ and from $3.00 \mathrm{pm}$ to $4.00 \mathrm{pm}$. The performances were very good only from $11.00 \mathrm{am}$ to $2.00 \mathrm{pm}$ with the percentages from $80.69 \%$ to $90 \%$.

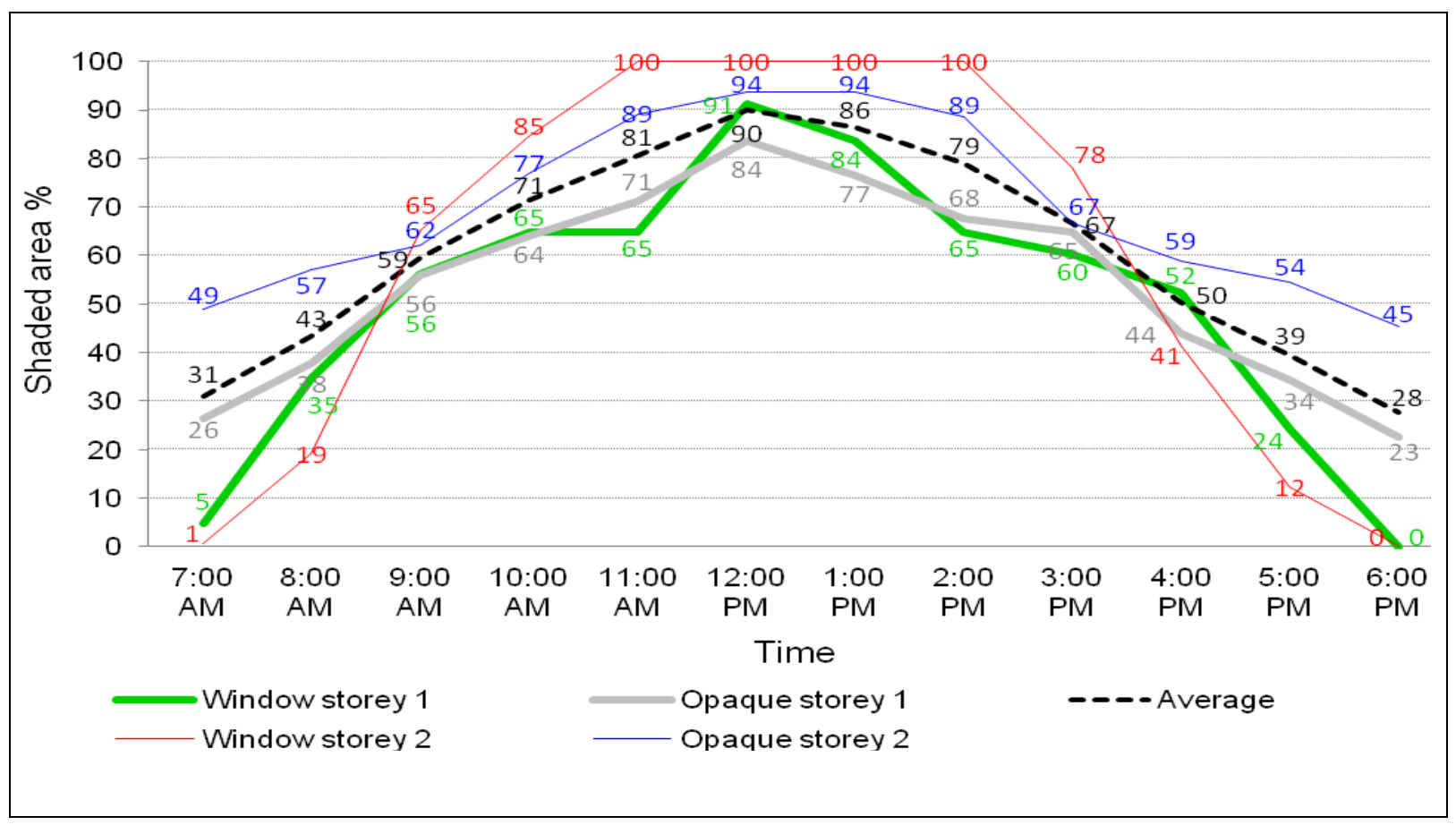

Figure 5. Percentages of shading area on a house facade in the Case Study A

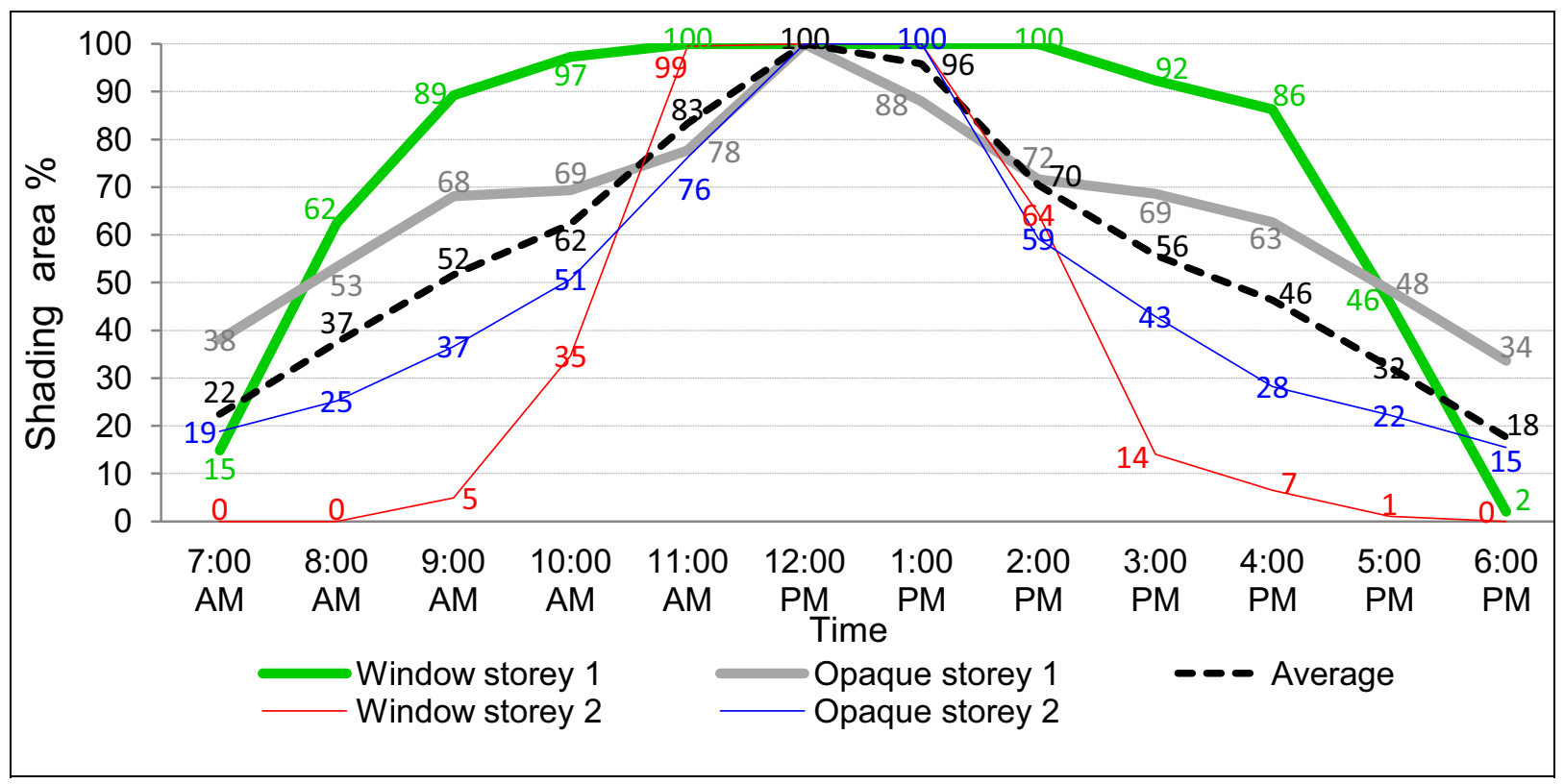

Figure 6. Percentages of shading area on a house facade in the Case Study B 


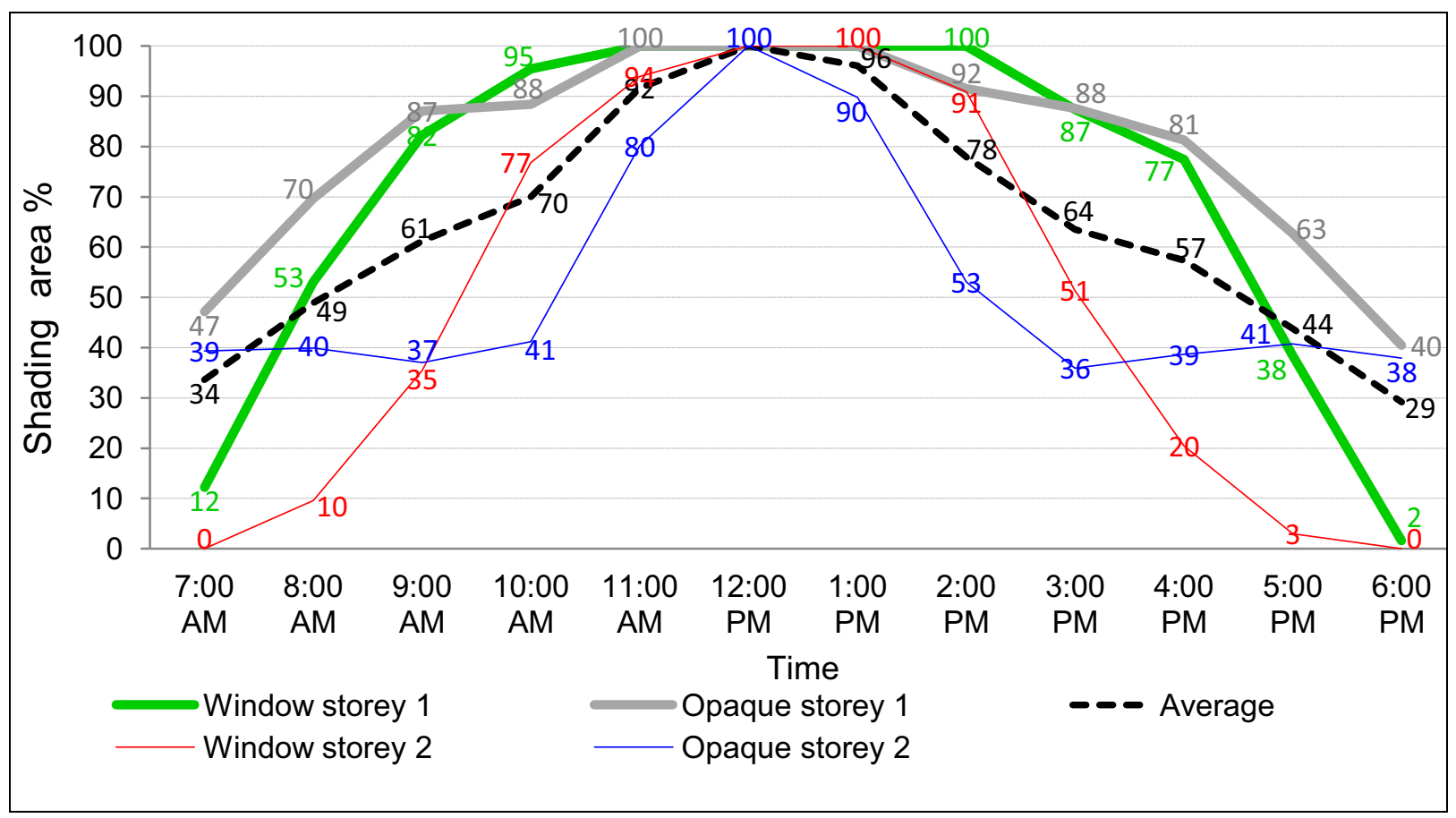

Figure 7. Percentages of shading area on a house facade in the Case Study C

For the Case Study $\mathrm{B}$, the performances were very weak at $7.00 \mathrm{am}$ and $6.00 \mathrm{pm}$ ranging from $17.68 \%$ to $22.46 \%$, and under weak category at $8.00 \mathrm{am}$ and from $4.00 \mathrm{pm}$ to $5.00 \mathrm{pm}$ ranging from $32.24 \%$ to $37.44 \%$. The performances were under intermediate category from $9.00 \mathrm{am}$ to $10.00 \mathrm{am}$ and from $2.00 \mathrm{pm}$ to $3.00 \mathrm{pm}$ ranging from $51.60 \%$ to $70.42 \%$ while they were very good from $11.00 \mathrm{am}$ to 2.00pm from $83.32 \%$ to $100 \%$. For the Case Study C, the performances from $7.00 \mathrm{am}$ to $8.00 \mathrm{am}$ and from $5.00 \mathrm{pm}$ to $6.00 \mathrm{pm}$ were under weak category ranging from $29.18 \%$ to $48.87 \%$, while under intermediate category from $9.00 \mathrm{am}$ to $10.00 \mathrm{am}$ and from $3.00 \mathrm{pm}$ to $4.00 \mathrm{pm}$ ranging from $57.33 \%$ to $69.97 \%$. The performances only had very good shade from $77.91 \%$ to $100 \%$, from $11.00 \mathrm{am}$ to $2.00 \mathrm{pm}$.

\section{DISCUSSION}

Sun angle in early morning and late afternoon is low which makes overhang roof design ineffective in all the case studies which had overall weak category from $4.00 \mathrm{pm}$ to $6.00 \mathrm{pm}$ as also argued by Zain-Ahmed (2000) in his thesis titled 'Daylighting and shading for thermal comfort in Malaysian buildings'. That is why the percentages of shading area in morning and late afternoon are less than its percentages at afternoon. Having exposed to direct morning sunlight is beneficial for acquiring adequate vitamin $D$ while exposure to direct evening sunlight is one of the causes of skin cancer (Skae, 2008). The reason for the percentage difference of the shading area between the Case Study A and Case Study B was due to the roof shape and the recessed porch type in the Case Study A which cover larger area of the house façade that provided permanent shade. Therefore, the Case Study A had higher percentage of shading area than the Case Study B. In addition, high angle sunlight provided the effectiveness of the roof overhangs; as a result, most parts of the house façade were under shade from 11.00am to 1.00pm in the Case Study A and B in its both Storey 1 and 2. The Case Study A had lower percentages of the shading area than the Case Study $C$ during morning, early afternoon and late afternoon. From the results it can be highlighted that both the Case Study $B$ and $C$ have the same porch depth. Shading percentage in the Case Study B however had lower percentages 
than the Case Study C during whole the daytime except at $12.00 \mathrm{pm}$ when both the house facades were fully under shade due to high angle sunlight.

\section{CONCLUSION}

In conclusion, the Case Study $\mathrm{C}$ had the highest average percentage of the shading area, which is $64.43 \%$, followed by the Case Study A $60.41 \%$ and Case Study B $56.29 \%$. The overall performance on average percentage of the shading area was $60.38 \%$. The overall shading performances in all the case studies were very good only from 11.00am to $2.00 \mathrm{pm}$ with the percentage of the shading area from $80.69 \%$ to $90 \%$. The overall performances however were under weak category mostly from $4.00 \mathrm{pm}$ to $6.00 \mathrm{pm}$ with an average below $40 \%$. These results showed that the facade designs had excellent horizontal shading elements with roof overhangs but they had weak vertical shading elements due to a lack of considerations for louvered elements to block low angle sunlight.

\section{REFERENCES}

Abdul Rahman, A. M. (1995). Housing design in relation to environmental comfort. Building Research and Information. Vol. 23, pp. 49-54.

Arab, Y. and Hassan, A.S. (2012). Daylighting analysis of pedentive dome's mosque design during summer solstice with case studies in Istanbul, Turkey. International Transaction Journal of Engineering. Management, \& Applied Sciences \& Technologies. Vol. 3(2), pp. 167-183.

Bakhlah, M.S. and Hassan, A.S. (2012). The study of air temperature when the sun path direction to Ka'abah: with a case study of Al-Malik Khalid Mosque, Malaysia. International Transaction Journal of Engineering, Management, \& Applied Sciences \& Technologies. Vol. 3(2), pp. 185-202.

Dale, W. L. (1964). Sunshine in Malaya. Journal of Tropical Geography. Vol. 19, pp. 20-26.

Danny, L.H.W. and Joseph, L.C. (2001). An analysis of climatic parameters and sky condition classification. Building and Environment. Vol. 36, pp. 435-445.

Department of Statistics Malaysia. (2000). General Report of the Housing Census. Putrajaya: Department of Statistics Malaysia Press.

Djamila, H., Ming, C.C. and Kumaresan, S. (2011). Estimation of exterior vertical daylight for the humid tropic of Kota Kinabalu city in East Malaysia. Renewable Energy. Vol. 36, pp. 9-15.

Feriadi, H. and Nyuk, H.W. (2004). Thermal Comfort for Naturally Ventilated Apartments in Indonesia. Energy and Building. Vol. 36, pp. 614-626.

Hassan, A.S. (1999). Putrajaya: The Direction of Malaysian New Town. Proceedings of the 5th International Congress of Asian Planning Schools Association (APSA). Seoul National University, Seoul, South Korea, pp, 165-175.

Hassan, A.S. (2001). Issues in Sustainable Development of Architecture in Malaysia. Penang: Universiti Sains Malaysia Press. 
Hassan, A.S. (2005). Konsep Rekabentuk Bandar di Semenanjung Malaysia: Kuala Lumpur dan BandarBandar di Sekitarnya. Penang: Universiti Sains Malaysia Press.

Hassan, A.S. and Ramli, M. (2010). Natural ventilation of indoor air temperature: A case study of the traditional Malay house in Penang. American J. of Engineering and Applied Sciences. Vol. 3, pp. 521-528.

Hussein, I. and Rahman, M.H.A. (2009). Field study on thermal comfort in Malaysia. European Journal of Scientific Research. Vol. 37, pp. 134-152.

Mazloomi, M., Hassan, A.S., Bagherpour P.N. and Ismail, M.R. (2010). Influence of geometry and orientation on flank insolation of streets in an arid climate city. American J. of Engineering and Applied Sciences. Vol. 3(3), pp. 540-544.

Nicol, F. and Humphreys, M. (2002). Adaptive thermal comfort and sustainable thermal standards for buildings. Energy and Building. Vol. 34, pp. 563-572.

Singh, M. K., Mahapatra S. and Atreya, S. K. (2010). Thermal performance study and evaluation of comfort temperatures in vernacular buildings of North-East India. Building and Environment. Vol. 45, pp. 320329.

Skae, T., 2008. The healing benefits of sunlight and vitamin D. Natural News. Taichung: Truth Publishing, Inc. [Online]. Retrieved January 12, 2013, from http://www.naturalnews.com/022889 Vitamin_D_sunlight_supplement.html

Zain-Ahmed, A., (2000). Daylighting and shading for thermal comfort in Malaysian buildings. Unpublished thesis in Doctor of Philosophy, University of Hertfordshire, United Kingdom.

Zain-Ahmed, A., Sopian, K., Abidin, Z.Z. and Othman, M.Y.H. (2002). The availability of daylight from tropical skies a case study of Malaysia. Renewable Energy. Vol. 25, pp. 21-30.

\section{ACKNOWLEDGEMENT}

The authors would like to express appreciation for the financial support under the Research University Grant by the Universiti Sains Malaysia. 